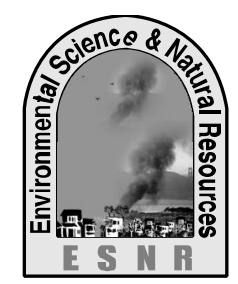

\title{
Waste Management Status of Shrimp Processing Plants of South and South- West Region of Bangladesh
}

\author{
M. I. Hossain, F. H. Shikha* and A. D. Sharma \\ Department of Fisheries Technology, Bangladesh Agricultural University, Mymensingh-2202, \\ Bangladesh \\ *Corresponding author: shikhafh@ bau.edu.bd
}

\begin{abstract}
The study was carried out on the present status of shrimp processing plantôs waste management in Bangladesh. A detailed survey was conducted during February to May, 2013 in order to collect some basic information on the present status of shrimp waste management at shrimp processing plants through questionnaire interview on the various parameters. Information was collected from 52 plants of Khulna, Chittagong and Cox`s bazaar region. All collected information were accumulated, analyzed and are presented in graphs, figures and tables. The study had revealed that about 671.84MT of shrimp was purchased in 52 plants in a day and from which 248.8 MT of waste product was produced during processing. The study results showed that about $80 \%$ of the plants sell their waste products and rest of the plants discharged their wastes into river $(63.50 \%)$ and $91.42 \%$ of the plants treated the waste water before discharge. Based on the obtained results from this study, it could be suggested that shrimp waste can be used further in different ecofriendly ways.
\end{abstract}

Key words: Bangladesh, Present status, Shrimp processing plant, Survey, Waste management

\section{Introduction}

Shrimp plays an important role in the economy of Bangladesh. It is the second largest export industries after garments from which Bangladesh earned as BDT 3640.2 crore in the year 2011-2012 (DoF, 2013). Among shrimp producing countries, Bangladesh ranks fourth in respect to area of shrimp farming and sixth in the volume of production. The fisheries sector including shrimp contributes about $4.39 \%$ to the national BDP and $2.46 \%$ to the national export earnings. Shrimp alone contribute about $54.2 \%$ of sectorial export earning and $2.46 \%$ of the national earning item in Bangladesh (DoF 2013). Shrimp export sector has grown over the past thirty years in response to expanded global demand. Expansion of shrimp processing industry has resulted in increased discharge of waste (Chandrkrachang et al., 1991). Shrimps are usually sold headless and often peeled of the outer shell, thus the waste generated comprises mainly of the shrimps head, shell and tail. It is reported that about $80 \%$ original weights of raw materials are discarded from shrimp and other crustacean in processing plants (Shahidi and Synowiecki, 1991). Shrimp waste meal has higher mineral, protein and calcium content than fish meal, as well as some amino acids such as aspartic acid, glutamic acid, leucine, lysine and argentine. Shrimp waste could be processed as several human food such as pettis (shrimp paste), terasi, shrimp crackers (Suparno and Poernomo, 1992). There is a great potential of utilization of shrimp processing biowaste in Bangladesh, if it could done in a suitable and feasible method. This could also help boost countries economy if proper attention paid to it. The word "Survey" refers to a method of study in which an overall picture obtained by a systemic collection of available data on the subjects (Efferson, 1953). It explains the selection of research area; identify target groups and selection of analytical method that have been used in the study area. According to Dillon and Hardaker (1993), there are three main methods by which survey data can be gathered. These are: i) Direct observation, ii) Interviewing respondents and iii) Records keeping by respondents. The study intends to investigate into the present status of biological waste management in shrimp processing industries of Bangladesh with a view to obtain some knowledge about their waste management system and to provide some guidelines which would be economically acceptable by utilizing this waste.

\section{Materials and Method}

The method of collecting data depends upon the nature, aim and objectives of the study. There are several methods of collecting data and information. Selection of particular method depends on many considerations such as the nature of the research problem, time constraints, availability of funds etc. The survey design of the present study is presented in Flow diagram-1. 


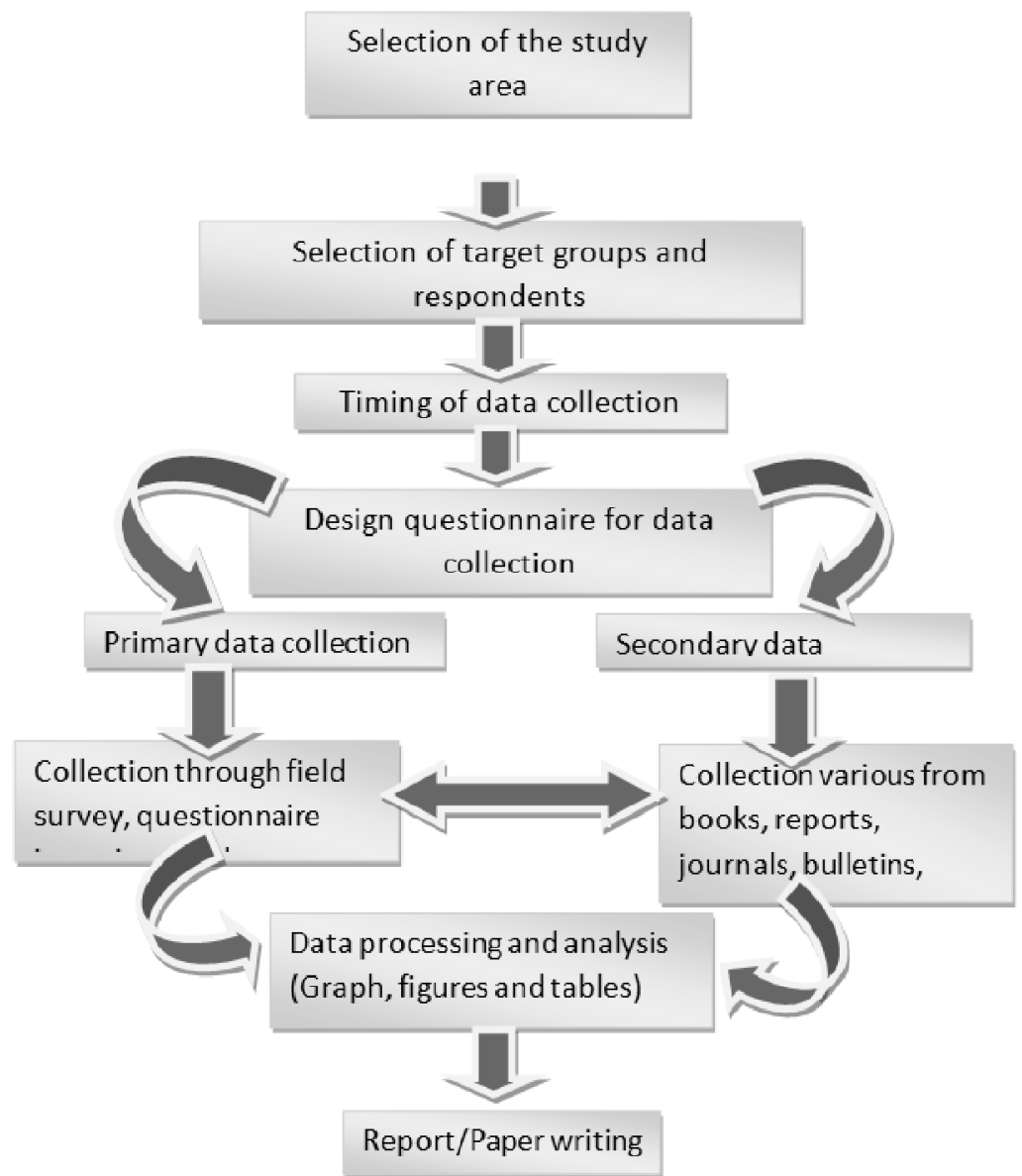

Flowchart 1. Methodology followed for the research

\section{Selection of study area}

Selection of the study area for the collection of data is based on the waste management in shrimp processing plant. Primary data collection requires selection of an area which would offer a scope to fulfill the objectives of the study. Before selecting a study area, two major factors were considered: i) What kind of data is required and ii) Overall environment of the area in which the expected data should be available. The study was conducted during July to October, 2013, among 100 shrimp (EU approved 75) processing industries randomly selected out of 52 industries in Khulna, Chittagong and Cox`s Bazaar districts. where most of the shrimp processing plant and waste processors are concentrated. Khulna, Chittagong and Cox`s Bazaar are the southern coastal city of Bangladesh.

\section{Survey design}

Collection of data is prerequisite for any farm management and research study. The method of collecting information depends on the purpose of the study undertaken. There are several methods of data collection. The survey method was used in the present study because it is the most appropriate method through which necessary information can be obtained within the shortest possible time and requires less expense than other methods.

\section{Preparations of questionnaire}

Questionnaire was prepared in accordance with the objectives set for the study. In order to get complete and reliable data, a draft survey schedule was prepared which include production and utilizing and management of those wastes in different industries (Plate 1 and 2). 

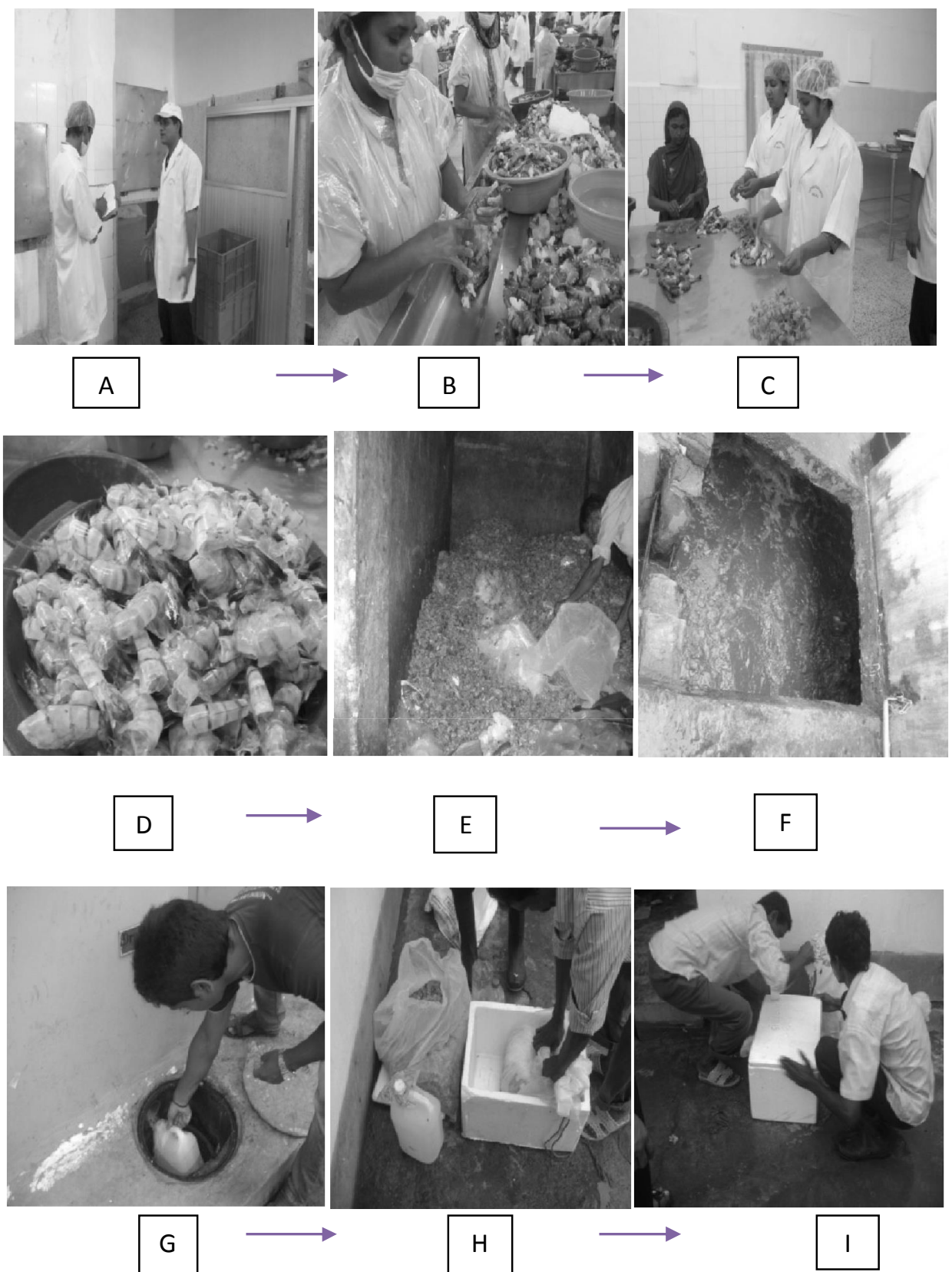

Plate-1. Collection of data and shrimp waste sample from Khulna and Chittagong region (inside the industry). (A) Questionnaire interview with resource person, (B) Removing shell by women, (C) Removing head women, (D) Shell of shrimp, (E) Dumping of shell and head of shrimp, (F) Treatment of waste water before discharge, (G) Collection of waste water, $(\mathrm{H})$ Collection of shrimp waste materials and water, (I) Packing of shrimp waste sample. 

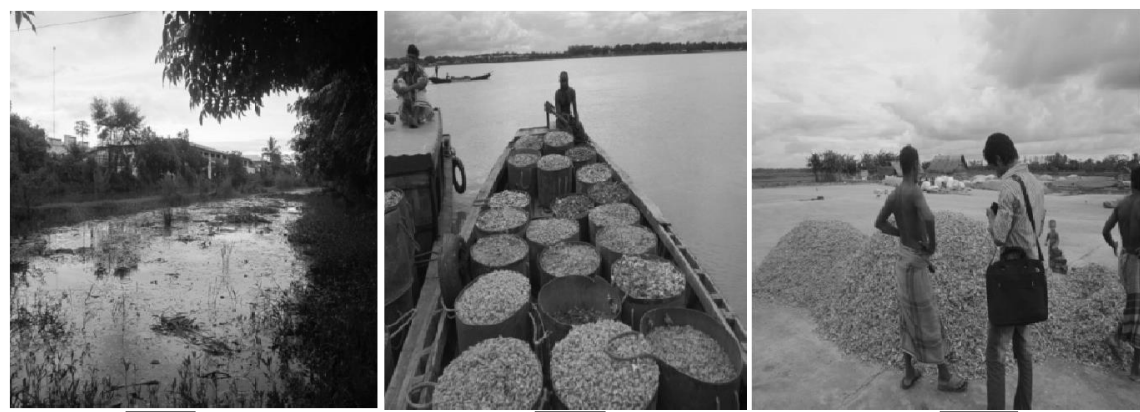

A
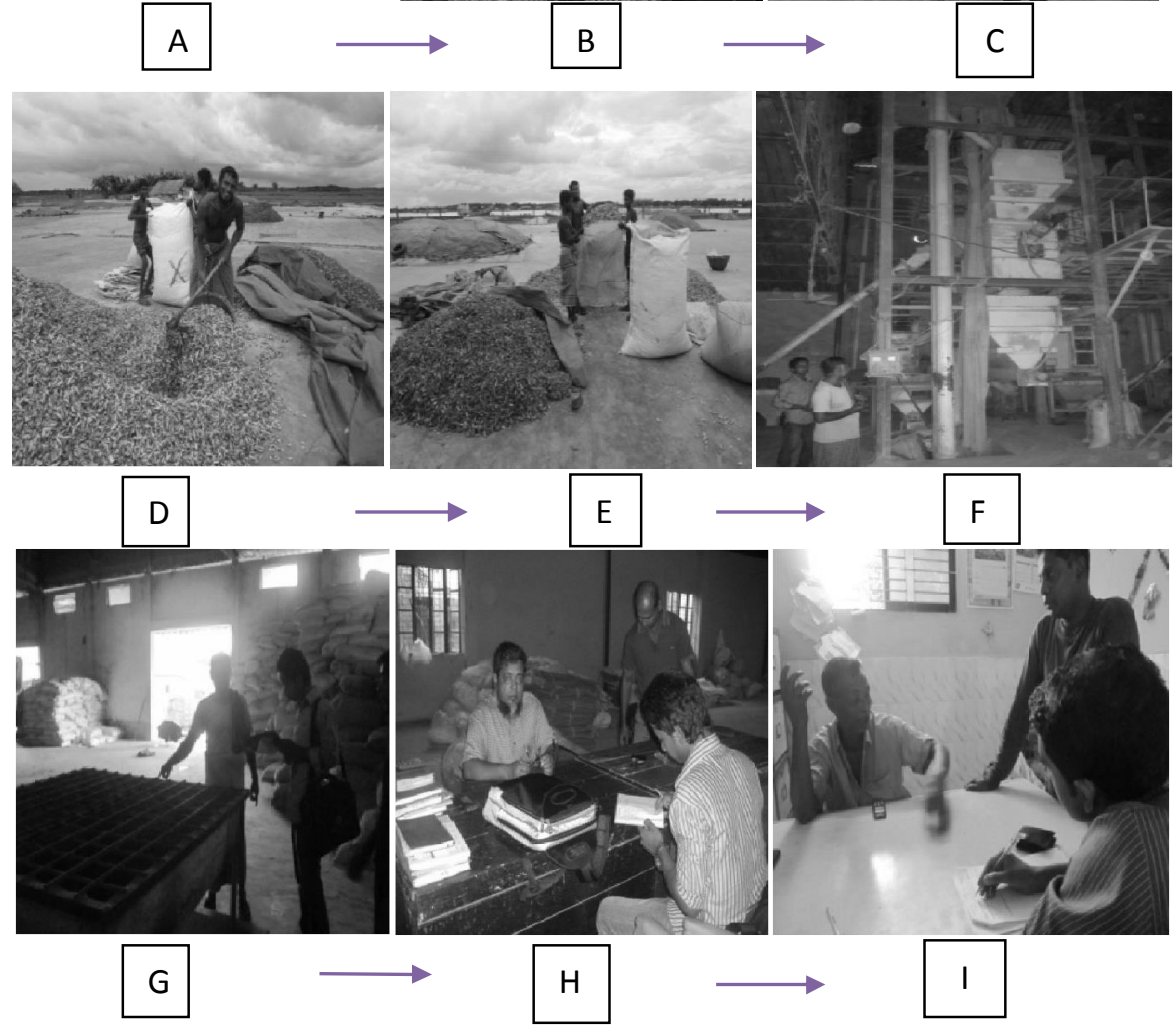

Plate-2. Collection of data and shrimp waste sample from Khulna and Chittagong region (outside the industry). (A) Discharge of waste water nearby canals, (B) Transporting shrimp waste at drying yard by engine boat, (C) Collection of information from resource person, (D) Drying of shrimp head and shell, (E) Packing dry shrimp wastes, (F) Inside view of the feed mill, $(\mathrm{G})$ Collection of information from farm labor, $(\mathrm{H})$ Collection of information from feed farm manager, (I) Collection of information from shrimp farmer.

\section{Questionnaire interviews}

The data was collected by using structured questionnaire interviews. The director and managers of the industries were interviewed to know the overall waste management system of the industries. The amount of waste production and their system of utilizing and management of those wastes in different industries were noted during personal visit to each of the industries. Data collected from one industry was cross-checked with those collected from other industries to rule out and/ or solved any inconsistency in the data through follow-up visits. The parameters selected for data collection were: i) Identification of the main occupation of the industry owners, ii) Types of ownership and investment pattern of the industries, iii) De-heading period, de-heading place and waste production volume per day of the industries, iv) Types of water used for washing shrimp, place of discharged waste water and treated of waste water before discharger or not, v) The management system of waste of those industries, vi) The utilization of shrimp waste after receiving from the industries, vii) Major problem and their future plan about waste management.

\section{Sound recorder and digital camera}

At the time of interview, the processing method, sanitation and hygienic condition of processing and sample picture were taken by camera.

For detail information sound recorder (mobile) was also used during data collection through interview. The primary data and information were collected in respect 
of operation and activities involved in smoked shrimp production systems, health and hygienic condition including socio-economic condition of smoked shrimp producers.

\section{Limitation of the study}

Finding slots from the director or managers of the industries from their apparently busy schedules was a problem thus several visits were required to find them available for interviews. Sometimes some of the managers were denied directly for interviews due to their lack of time. The time limit of survey was not sufficient. As well some of the interview may have a biased answer to question asked. However the survey was completed.

\section{Data analysis}

All the collected information from the different processing industries were accumulated and analyzed by MS Excel. The data were then presented in graphs, figures and tables.

\section{Results and Discussion}

\section{General information}

Fishery sector has become very important for its inherent potential to fulfill protein for the countries people, export earning and employment generation. Bangladesh is the only country producing tasty, natural and chemical free shrimp in the world. In the national export earning, shrimp and other fishes contributed about 4.39 percent in value of total fisheries. Although the present contribution of shrimp is already huge, it is nothing more than a small part of its full potential. Currently about 2, 75,232 hector suitable brackish water areas are being utilized for shrimp farming. At present production level of shrimp in our country is not satisfactory. It is also considerably lower than Thailand, India, Vietnam, China, and Indonesia. Therefore, Bangladesh has a tremendous potential for both vertical and horizontal expansion of shrimp farming. Increasing the production several fold from such a low base line should be possible if adequate infrastructure and technological supports are provided. In this regard, shrimp processing industries are going to play a vital role in the coming years through their full capacity utilization from their current facilities (Table 1) or expansion of new facilities to cope up with the processing of increased shrimp production.

Table 1. Basic information on frozen food industry in Bangladesh

\begin{tabular}{cc}
\hline No. of fish processing plant & 100 \\
\hline Kish processing plant approved by the EU-(Chittagong-16, & 75 \\
Processing capacity of production plants & \\
Export earnings from frozen foods in 2012-2013(shrimp \& prawn) & 30-60MT per Day \\
Quantity of frozen food exported in 2012-2013(shrimp \& prawn) & 36402 million \\
No. of shrimp hatchery & 48007 MT \\
Shrimp culture land & Golda hatchery 70 (govt.17), \\
Production of shrimp and prawn & Bagda hatchery 61 (govt.2) \\
Production of shrimp fry(PL) & $2,75,232$ hector \\
& $1,96,306 \mathrm{MT}$ \\
& Bagda 8200million,
\end{tabular}

\section{Types of shrimp purchase}

The study was conducted to find out the types of shrimp purchase in different industries. The study results revealed that about $90 \%$ of the industries purchased head-on shrimps. The rest of $10 \%$ of the industries purchased both headless and head-on shrimps (Fig. 1). There was no industry that purchased only headless shrimp. This was because both headless and head-on shrimp. This was because both headless and head-on shrimp were exported to foreign countries. Both types of shrimp had demand in consumer countries.

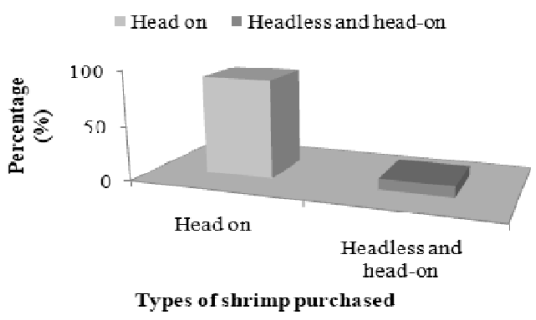

Fig. 1. Percentage of different types of shrimp purchased Production volume/day 
The data collected on the production volume of different industries is shown in Fig. 2. The figure shows that most of the industries $(28.7 \%)$ production was 4 to $10 \mathrm{MT} / \mathrm{day}$. About $9.5 \%$ of the industries whose production was comparatively high than others
(25 to $31 \mathrm{MT} /$ day). The total production of the 52 industries was estimated to reach at $672 \mathrm{MT} /$ day (approximately). The average production was calculated at $12.92 \mathrm{MT} /$ day/industry.

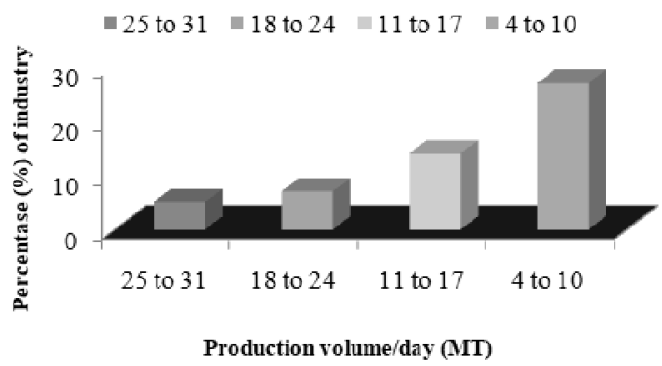

Fig. 2. Production volume of different industries

\section{Waste production/day}

Survey was conducted to find out the total waste production of shrimp in each industry. The survey result revealed that the total waste production of the 52 processing plants was $248.8 \mathrm{MT} /$ day. The average production of shrimp in a processing plant was 3.86 MT/day. From the data it was found that the total shrimp production of the 52 processing plants was 672 MT/day whereas the total waste production was 248.8 MT/day which showed that the waste production is about $37 \%$ of the total shrimp production (Fig. 3). It implies that from different types of shrimp average $37 \%$ weight of waste was produced which was discarded. About shrimp waste production in shrimp processing industries and environmental issues relating to this waste, several researchers have conducted studies. Among them Chandrkrachang et al. (1991) reported that first expansion of fish and shrimp culture industry in many Asian countries has result discharge of waste and created a serious environmental and hygienic problem. Shahidi and Synowiecki (1991) noted that on a global scale over $90 \%$ of frozen shrimp is exported, only less than $10 \%$ for domestic use.

Thus an assessment of shrimp waste from frozen shrimp export is about 580,000 MT and in a global basis the shrimp processing industry (including canning and frozen) produces over 700,00 MT. Discarded from crustacean processing plants is about $80 \%$ original weight of raw materials. Suparno and Poeronomo (1992) found that the waste is closely related to post harvest losses.

In Indonesia, this term is more specially defined as material which is discarded from treatment and processing of main products and by-products. Fish processing industries generates substantial amounts of waste which might create environmental problems because of easily degradable content such as protein, fat and produced organic compound. Therefore interests due to technological innovation in the utilization of shrimp waste leading to several products of high economic value, supplementary protein source both for animal and human and to solve environmental pollution created by waste. Subasinghe, (2003) found that traditional disposal method of waste coupled with strengthening environmental regulation in many countries has created interest in alternative methods of disposal and also potent economic benefits of waste. The raw material determines the suitability and feasibility of value addition.

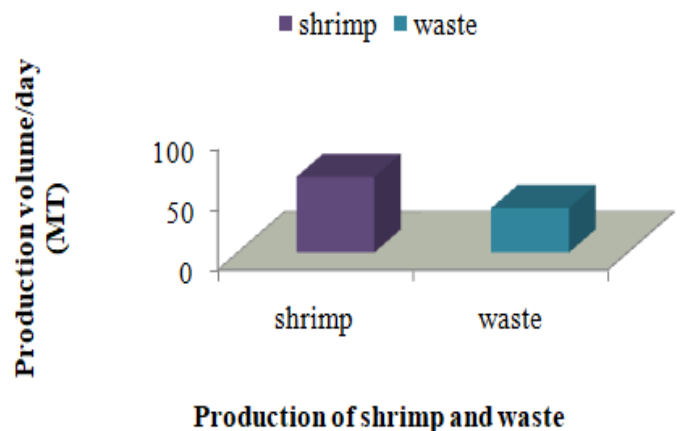

Fig. 3. Production of shrimp and waste per day 


\section{Waste production from different body parts}

The survey result of the waste production of different body parts of shrimp is shown in Table 2. It was found that, from Golda about $45 \%$ waste was produced from the whole body weight, whereas from Bagda about $35 \%$ waste was produced. Both of those $45 \%$ and $35 \%$ waste was produced from the head of the shrimp. Harina and Chaka was produced about 32 to $37 \%$ waste. From the other parts of the body, waste was produced as $15 \%$ from the tail and legs and $1.5 \%$ from the other body parts. The similar types of studies were carried out by other scientists in different countries. A group of scientists, Kungasuwan et al. (1996) reported that from shrimp industries, shrimp bio-waste have generated i.e. head, shell and tail are available and the waste left over is as high as $40 \%$ of raw total weight. It was reported that head $25 \%$, shell $10 \%$ and tail $5 \%$ generated as waste, respectively. Part of the bio-waste is sold for animal feed production. Subasinghe (1999) reported that when processed is headless, shell on products; shrimp raw material is discarded about 30$45 \%$ as waste by weight. Peeling processed involves removal of shell from prawn; increase the total waste production up to $45 \%$. Lopez et al. (2002) reported that only $55 \%$ of this animal (shrimp) is edible and rest is composed of inedible cephalothoraxes and exoskeleton. This fraction represents 35000 MT/year of potentially polluting waste in Mexico.

Table 2. List of percentage of waste production from different body parts of shrimp

\begin{tabular}{|c|c|c|}
\hline Body parts & Type & Percentages (\%) \\
\hline \multirow{3}{*}{ Head and shell } & Golda & 45 \\
\hline & Bagda & 35 \\
\hline & Harina \& Chaka & $32-37$ \\
\hline Tail & & 15 \\
\hline Others & & 1.5 \\
\hline
\end{tabular}

\section{Water used for washing shrimp}

The survey result revealed that before using the water for washing shrimp it was penetrated following different stages. The overall treatment system was nearly same among the processing plants; very few were following different chemicals or materials whereas other followed the same chemicals ingredients. The overall system may be explained as following; i) Filter (sand) + Reactivated carbon filter, ii) Iron removes by ozone treatment, iii) Aeration tower, iv) U.V treatment, v) Washing with chlorinated water (different concentration of chlorine was used at different stages), vi) Chilled water at 20C (after panning and glazing).

\section{Source of water supply}

Water supply is one of the most important considerations for any of the processing plants.
Because pure water supply is essential for the ice making, washing, panning, glazing. This survey result revealed that the plants had deep tube well as their main water supply. They established deep tube well in their processing area by which they pump out underground water for different purposes. No other alternate source was found during the survey.

\section{Discharge waste water}

Waste water disposed area is one of the important things taken in consideration for each of the processing plants as there is a consequence of environmental pollutions. The survey results revealed that most of the plants discharged their waste water in river $(63.50 \%)$ as the plants were situated beside the river. Table 3 shows that others discharged their waste water in nearly drains $(5.76 \%)$, canals $(30.75 \%)$.

Table 3. List of different types of waste water disposal area

\begin{tabular}{ccc}
\hline Type & Frequency & Percentage (\%) \\
\hline River & 33 & 63.50 \\
Canal & 16 & 30.75 \\
Drain & 3 & 5.76 \\
Total & 52 & 100 \\
\hline
\end{tabular}


Pretreatment of waste water before discharge

Survey was conducted to find out whether the plants usually treat their waste water before discharging. The survey results revealed that most of the plants $(91.42 \%)$ treated their waste water before discharging whereas the rest of $8.57 \%$ of plants did not treat their waste water before discharging out of their industries
(Fig. 4). It was good news for us that the plants have taken the environmental issues in their consideration. However, in many Asian and other advanced countries, this waste water are used for extracting many commercially valuable organic materials like as chitin, chitosan, enzymes and so on. Unfortunately, in our country no such activities were found.

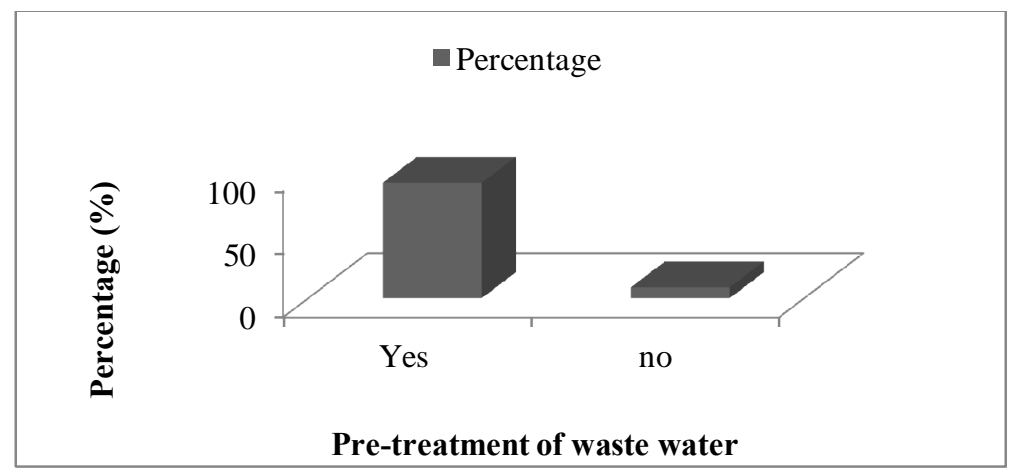

Fig. 4. Percentage of pretreatment of waste water discharge

\section{Fate of the waste product}

The survey result on the fate of solid waste product is given in Table 4 . The survey result showed that most of the $(80 \%)$ waste products were sold out at different prices. About $14.28 \%$ plants were found who gave it to

\section{Table 4. List of different types of waste management system}

\begin{tabular}{ccc}
\hline Type & Frequency & Percentage (\%) \\
\hline Sell & 35 & 67.30 \\
Discard & 11 & 21.15 \\
Give away & 6 & 11.54 \\
Total & 52 & 100 \\
\hline
\end{tabular}

\section{Present uses of shrimp waste}

The shrimp wastes were discarded in the municipal dumping yard in Chittagong and Coxôs bazaar region. No factories currently have developed the technique to use the waste as by-product. Some factories sold the raw waste materials through contraction. The contractor dried the raw materials in the own drying yard. Some companies were brought the dry waste from the contractor. Sundried products have strong bad smells. Presently 3 to 4 companies (Jing Ying Trading Ltd., S.H. Trading, SAT Trading, China Sea Food, Jai Jiang Anji etc.) buy sun dried products in 400-600 Kg bails in Khulna region.

\section{Price of waste products}

Survey was conducted to find out price of waste products sold by the different plants. The survey result showed different varieties of prices of shrimp waste per $\mathrm{Kg}$. The average value was calculated at Tk. 6.5 per $\mathrm{Kg}$. The price of shrimp waste per $\mathrm{Kg}$ fluctuated the people who were interested to take it. The rest of $5.71 \%$ of plants discarded their waste product. As there was no opportunity for selling out those waste products, the plant managers discarded it anyway.
$\mathrm{Kg}$. Dry head and shell was sold Tk.25 per Kg.

\section{Discharge place of shrimp waste}

From the study it was found that some of the plants discarded their waste at different place. The discharged places were identified, i) In Khulna region, waste materials were sold to the contractors. They dried and sold it to China companies and ii) In Chittagong, the wastes were dumped in municipal dumping yard.

\section{Major problems in waste management}

Problem in waste management was one of the important considerations taken in account to overcome the problem. Survey was conducted to find out the major problem faced by the processing plants. The survey report revealed that no major problem was pointed out by the interviewee. Because they can sell it to the buyers as the price was not a fact. The buyers himself bought the waste willingly. The plant had taken responsibility only to sell it to the buyers. After 
then what was happening with the waste materials was not a headache of them. If there was no customer to sell it then they usually give it to the interested people are found. This may be taken as a minor problem as a very few of the plants were faced such a problem. When they faced such a problem then they manage to bury the wastes into a pile beneath the ground or thrown it to the unused closed water body area adjacent to the plants which may cause a problem. This types of problem can be considered as a minor problem because it problem. This type of problem can be consideration as a minor problem because it happens only a few times. Besides, no other problem was identified during the survey period.

\section{Conclusion}

In general, the present status of shrimp waste processing is unscientific and unhygienic compared to other countries. The system of shrimp processing waste outside the industries areas causes a serious environmental pollution occupying a large area. The present study observed that the industries discharge their waste water to the river though they claimed that those are treated before being discharged. The industries managed the waste product only if it could be sold, otherwise they just through it anyway. Some of them were trying to use it in scientific way but the proportion was not considerable. The most utilization of those processing waste was found in the form drying and sold in china companies like Jing Ying Trading Ltd., S.H. Trading, SAT Trading, China Sea Food, Jai Jiang Anji etc. It was found that about one third of surveyed industries have a future plan for producing economically viable product in scientific and environmentally sound way. For the purpose government and non-government agencies, research organization, local administration and university should co-operate together to formulate an integrated policy to intelligently manage and utilize shrimp processing waste. It is required, not only the modern technology but also pro-active authorities to utilize the shrimp processing waste and hence improve the economic conditions of the countries, industries and people engaged in this related work. Quality and safety assurance are important elements in shrimp processing, with the finished product increasingly having to meet the market's stringent requirements. While the shrimp processing waste offers an excellent source of protein replacement in shrimp feed formulation, to the best of the author's knowledge, no such study has yet been undertaken to exploit this alternative. Even there has been a dearth of knowledge as to the present status of shrimp processing waste production. The present study has been a preliminary effort toward this end. Utilization of shrimp processing waste as an alternative to fish meal in shrimp diet would maintain a hygienic work area while bringing the production cost down to a sustainable level through waste reclamation. Besides, results of this study would give the way for development of a backyard industry to ensure alternative sustainable livelihood for the underprivileged workforce engaged in the non-formal sector of the shrimp industry.

\section{Acknowledgement}

The study was done with the financial support of Ministry of Science and Technology, Peopleôs Republic of Bangladesh.

\section{References}

Chandrkrachang, S., Chinadit, U., Chandayot, P., Supasiri, T. 1991: Profitable spin-off from shrimp-seaweed poly culture. INFOFISH International, 6: 26-28.

Dillon, J. L., Hardeker, J. B. 1999. Farm management research for small farmer development, FAO, Farm system manages, 6: 302.

DoF. 2013: National Fish Week 2013 Compendium (in Bengali), Department of Fisheries, Ministry of Fisheries and Livestock, Bangladesh, 127130.

Efferson, T. N. 1953: Principle of Farm Management. McGraw-Hill, New York, 431.

Kungsuwan, A., Ittipong, B., Chandrkrachang, S. 1996: Preservative effect of chinosan on fish products, Chitin and Chitosan-proceedings of the second Asia Pacific Symposium (eds), 193-199.

Lopez, R. A., Guerrero, L., Huerta, S. 2002: Astaxanthine extraction from shrimp waste by lactic acid fermentation and enzymatic hydrolysis of the carotenoprotein complex. Journal of Food Science 67(3) :1002-1006.

Shahidi, F., Synowiecki, J. 1991: Isolation and characterization of nutrient and value added products from snow crab (Chinoectes opilio) and shrimp (Peneaus monodon) processing discards. Journal of Agricultural and Food Chemistry, 39: 1527-1532.

Subashinghe, S 2003: Shrimp an ideal candidate for value addition. INFOFISH International, 5: 45-50.

Subashinghe, S. 1999: Chitin from shell fish waste health benefit overshadowing industrial uses. INFOFISH International, 3: 57-63.

Superno, Poernomo A. 1992: Fish waste utilization in Indonesia ASEAN Food Journal (Malaysia), $7(2)$ : 67-72. 